\title{
Combinations of heat pump and photovoltaics for renovated buildings
}

\author{
Andreas Heinz $^{1 *}$ and Christian Gaber ${ }^{1}$ \\ ${ }^{1}$ Graz University of Technology, Institute of Thermal Engineering, 8010 Graz, Austria
}

\begin{abstract}
The aim of this work is the analysis of hybrid heating systems consisting of an air source heat pump, a storage tank and a photovoltaic (PV) system for the use in renovated residential buildings. The potential for decreasing the electrical energy consumption of the heat pump from the grid by targeted operation of the speed controlled compressor with electricity from PV is determined by means of dynamic system simulations in TRNSYS for a renovated single family house under the assumption that the existing radiator heating system is not replaced, and that therefore relatively high supply temperatures are necessary. Different variants were considered with regard to the size of the PV system, the storage volume and the influence of the heat emission system.
\end{abstract}

\section{Introduction}

The building sector plays a central role in achieving energy and climate policy objectives. In Austria more than one third of the final energy consumption is used to provide space heating, hot water and cooling in residential and service buildings. With a construction rate of new buildings of only about $1-2 \%$ per year, the greatest energy saving potential lies with existing buildings in need of renovation. Since around 1.5 million of the 2 million buildings in Austria fall into the single-family or two-family house category, this is also where the highest savings potential lies. With regard to the construction periods, the highest potential lies with buildings built between 1961 and 1980, especially since about one third of the entire Austrian building stock was constructed in this period [1].

Thermal renovation together with the replacement of inefficient, fossil fuel based heating systems provides a large potential for energy savings. Air-to-water heat pumps are in principle an attractive alternative heating system for such buildings due to relatively low investment costs and simple installation. However, this solution is often not implemented due to the heat emission system, which usually consists of radiators, that are often not replaced during a building renovation due to cost reasons. Therefore, relatively high supply temperatures are required, which sets limits to the efficiency of the heat pump.

At the same time the demand for solutions enabling a high self-consumption of electricity from PV plants has strongly increased due to the decrease of feed-in tariffs for PV electricity and as possibility for stabilizing the electricity grid. Strategies for increasing PV selfconsumption for heating systems with heat pumps have recently been analysed by system simulations in [2] for an air source heat pump, in [3] for a ground source heat pump system, and in [4] for an air- and ground source heat pump, all of them reporting promising results.

In this work the potential for decreasing the electricity consumption of the heat pump from the grid by driving the compressor increasingly with electricity from PV is analysed for a typical situation of a renovated single family building by means of system simulations in TRNSYS.

\section{Boundary Conditions / Assumptions}

\subsection{Climate, building and domestic hot water}

As climate data set a "Test Reference Year", as described in [5], for the city Zurich is used. The mean outdoor temperature over the year is $9.1{ }^{\circ} \mathrm{C}$, the solar radiation on a $45^{\circ}$ inclined surface facing south sums up to $1306 \mathrm{kWh} /\left(\mathrm{m}^{2} . \mathrm{a}\right)$ and to $1111 \mathrm{kWh} /\left(\mathrm{m}^{2} . \mathrm{a}\right)$ on the horizontal.

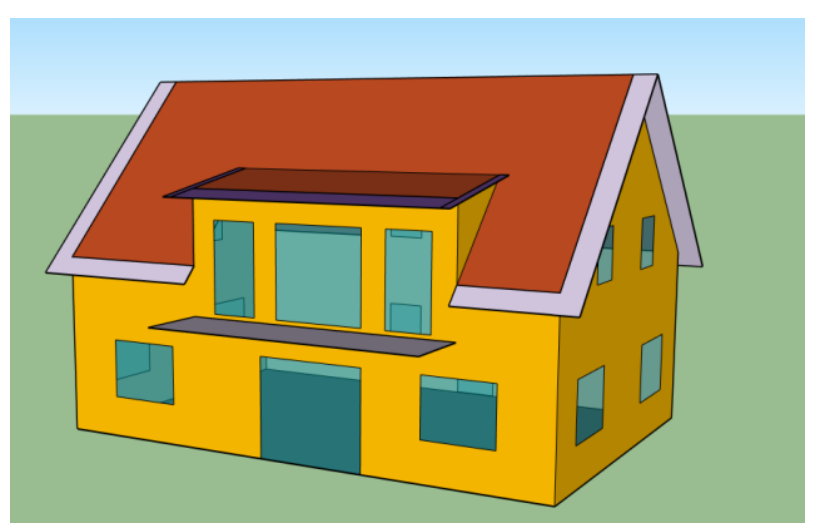

Fig. 1. Reference single family building

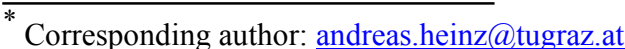


A single-family house with a heated floor area of $185 \mathrm{~m}^{2}$ was defined as the reference building (Fig. 1) in two variants concerning the thermal insulation standard and was modelled in the simulation software TRNSYS:

- Before renovation

- After renovation (usual renovation)

The wall structures were chosen on the basis of building typologies for Austria defined in the European project TABULA [6]. The starting point was a building of the age class 1960-1981 with the according wall structures as defined in TABULA, which defines the variant "before renovation". For the "after renovation" scenario, a "usual renovation", like it is defined in TABULA with according wall structures, was used.

All assumptions regarding the air exchange (incl. additional window ventilation in summer) and the shading of the building were taken from the reference building model of the IEA SHC Task 44 [7]. The software "Load Profile Generator"[8], which was developed as part of a dissertation at Chemnitz University of Technology [9], was used for the internal heat gains from devices and lighting as well as from persons present in the building. Load profiles were created for a household with 4 persons (both parents working, two school-age children) stored as a template in the software. For the heat gains by devices and for the presence of persons, a separate load file for the TRNSYS simulation was created.

The resulting load profile for devices and lighting was created with a resolution of one minute and results in electrical gains totalling $16.4 \mathrm{kWh} / \mathrm{m}^{2}$.a. The same profile is also assumed for the consumption of household electricity with a total of $3058 \mathrm{kWh} / \mathrm{a}$. For the persons present, a sensitive heat output of $60 \mathrm{~W}$ per person and a latent heat output of $40 \mathrm{~W}$ were assumed according to ISO 7730.

The simulation results show a space heating demand of 38670 and $12212 \mathrm{kWh} / \mathrm{a}$ and a heat load of 15.4 and $7 \mathrm{~kW}$ for the building before and after renovation respectively, assuming a room set temperature of $22{ }^{\circ} \mathrm{C}$. For all the simulations shown in this work the renovated building scenario was used.

The tap profile for domestic hot water (DHW) was taken from the FP7 project MacSheep [5]. The latter was created with the DHWcalc software [10] and has a total heat demand of $3038 \mathrm{kWh}$.

\subsection{Heat emission system}

For the heat emission system, radiators with a radiator exponent $\mathrm{n}=1.3$ were assumed. For the "before renovation" scenario, a flow temperature $\mathrm{t}_{\mathrm{fl}}=90^{\circ} \mathrm{C}$ and a return temperature $t_{\text {ret }}=70^{\circ} \mathrm{C}$ were assumed for the heating load $\dot{Q}_{100}$ in the design point (design ambient temperature $-11^{\circ} \mathrm{C}$ ), which was still common for heating systems built in the 1960s and 70s according to [11] and [12]. For the "after renovation" variant, the necessary $t_{f l}$ and $t_{\text {ret }}$ were determined for the reduced heating load of the renovated building assuming constant heating surfaces. Thus, at $-11^{\circ} \mathrm{C}$, the flow temperature is $58^{\circ} \mathrm{C}$ and the return temperature $48.9^{\circ} \mathrm{C}$ (see Fig. 2).
Additionally, simulations with a floor heating system with $35 / 30{ }^{\circ} \mathrm{C}$ at the design ambient temperature were performed to enable a comparison and an analysis of the influence of the system temperatures.

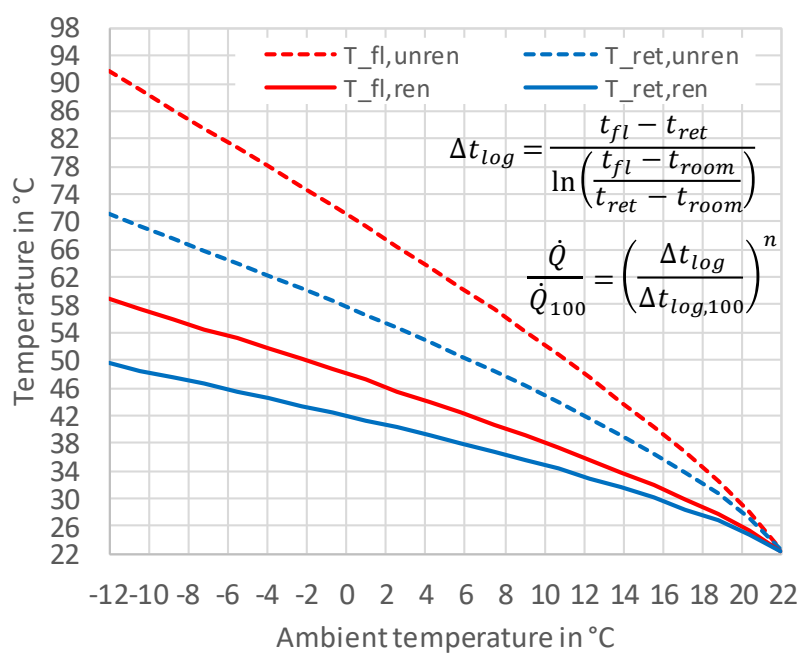

Fig. 2. Flow and return temperatures for the renovated (ren) and unrenovated (unren) building scenario

\subsection{Heat pump}

For the simulation of the air-source heat pump the semiphysical model Type 887 was used [13], considering the thermodynamic properties of the refrigerant and the detailed compressor performance data of a real compressor depending on the evaporation, condensation temperature and the compressor speed, as well as taking into account the operational limits (max. condensation and min. evaporation temperature depending on the speed). The heat pump uses propane (R290) as refrigerant and the compressor speed can be continuously reduced to $30 \%$ of the maximum. The parameterized heat pump model results in a thermal capacity of $6.75 \mathrm{~kW}$ and a COP of 2.69 at the operating conditions A-10W 35 and $10.4 \mathrm{~kW}$ and COP 3.5 at A2W35, both at full compressor speed.

\subsection{System layout heating system}

The hydraulic layout of the air-source heat pump system assumed for the simulations is depicted in Fig. 3. The heat pump is connected to a storage tank with a volume of 1000 litres. The heat losses of the tank were assumed with efficiency class B according to [14]. Using three-wayvalves the heat pump can charge either the DHW zone of the tank via the two connections on the top or the space heating zone via the lower connections. The storage tank is connected to the heat pump in parallel to the space heating system. This means when the store is being charged for space heating by the heat pump, some of the flow will go via the space heating distribution loop and the rest will go through the store. The proportions depend on the current operating conditions (current flow) of the space heating loop. DHW preparation is done via a freshwater station (external plate heat exchanger) to a temperature of $45^{\circ} \mathrm{C}$. In the simulations two additional storage sizes (1500 and 2000 litres) were considered, 
assuming the same relative heights of the connections and sensors, as shown in Fig. 3.

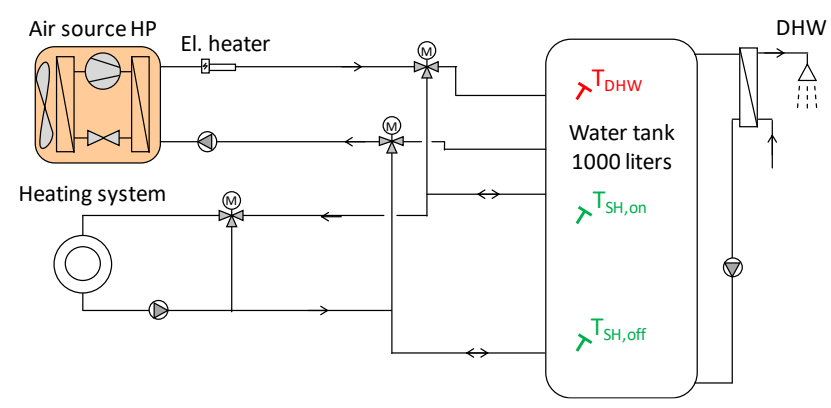

Fig. 3. Hydraulic layout of the heating system

The heat pump is operated with constant speed (90\% of the maximum) during DHW charging mode. In space heating mode the speed is adapted, in order to reach the flow temperature according to the heating curve (Fig. 2) at the outlet of the heat pump. The electrical heater in the flow line of the heat pump with a thermal output of $9 \mathrm{~kW}$ is activated, when the heat pump has not reached the required temperature 30 minutes after its activation.

The space heating loop uses a mixing valve in order to set the flow temperature according to the heating curve and the flow rate is assumed to be controlled by a thermostatic valve in order to reach $22^{\circ} \mathrm{C}$ room temperature.

\subsection{Photovoltaic system}

The building is assumed to have a PV system installed on the roof, facing south with an inclination of $45^{\circ}$. Three different PV sizes are analysed in the simulations: $55 \mathrm{~m}^{2}$ $(9.3 \mathrm{kWp}), 40 \mathrm{~m}^{2}(6.8 \mathrm{kWp})$ and $25 \mathrm{~m}^{2}(4.2 \mathrm{kWp})$. With the assumed boundary conditions the annual PV yields for the three PV sizes are 8452, 6147 and $3842 \mathrm{kWh}$.

\subsection{Control Strategy}

For the control of the system three strategies are analysed and compared:

- PARALLEL: This is the basic control strategy used for charging the storage tank. PV is only used by the heat pump if it is in operation by coincidence, when $\mathrm{PV}$ electricity is available. Charging of the DHW zone of the tank by the heat pump is started, if $\mathrm{T}_{\mathrm{DHW}}<45^{\circ} \mathrm{C}$ (sensor position in Fig. 3) and is stopped, when $\mathrm{T}_{\mathrm{DHW}}>55^{\circ} \mathrm{C}$. The space heating zone is charged, if $\mathrm{T}_{\mathrm{SH}, \mathrm{on}}<\mathrm{T}_{\mathrm{fl}}$ and stopped when $\mathrm{T}_{\mathrm{SH}, \text { off }}>\mathrm{T}_{\mathrm{fl}}+2 \mathrm{~K}$, where $\mathrm{T}_{\mathrm{fl}}$ is the flow temperature depending on the ambient temperature (Fig. 2).

- WIN: This strategy is equal to the strategy PARALLEL, with the exception that charging of the DHW zone is only possible in a time window from 12:00 to $14: 00$, in order to shift DHW operation into times, when PV electricity is usually available and also the ambient temperature is relatively high.

- WIN\&PV: This strategy is equal to the strategy WIN and additionally the heat pump is operated whenever the available PV electricity exceeds the household electricity demand by $0.7 \mathrm{~kW}$. The speed of the compressor is adapted, in order to match the consumption of the heat pump to the available PV excess electricity (eq. (2)). In this "PV-operationmode" the entire storage tank is overheated to max. $60{ }^{\circ} \mathrm{C}$, when the ambient temperature is higher than $-5^{\circ} \mathrm{C}$ and to $55^{\circ} \mathrm{C}$ if it is lower, due to the operational limits of the compressor. Overheating of the building itself is not considered.

\section{Key Performance Figures}

In order to enable a comparison of the analysed variants of the system the following performance figures were defined, all of them on an annual basis. The focus is on the electricity consumption from the grid $W_{e l, s y s, g r i d}$, which is important both concerning operating costs and $\mathrm{CO}_{2}$ emissions, and the PV electricity feedin $W_{\text {el,feedin }}$.

$$
\begin{aligned}
& W_{\text {el,sys }}=\int\left(P_{\text {el,HP }}+P_{\text {el,pumps }}+P_{\text {el,heater }}\right) d t \\
& P_{e l, P V, e x c}=\max \left(\left(P_{e l, P V}-P_{e l, h h}\right), 0\right) \\
& W_{\text {el,sys,grid }}=\int \max \left(\left(P_{\text {el,sys }}\right.\right. \\
& \left.\left.-P_{e l, P V, e x c}\right), 0\right) d t \\
& S P F_{s y s, P V}=\frac{\int\left(\dot{Q}_{S H}+\dot{Q}_{D H W}\right) d t}{W_{e l, s y s, g r i d}} \\
& W_{\text {el,feedin }}=\int \max \left(\left(P_{e l, P V, e x c}\right.\right. \\
& \left.\left.-P_{e l, s y s}\right), 0\right) d t
\end{aligned}
$$

$P_{\text {el,HP }} \quad$ el. consumption heat pump

$P_{\text {el,pumps }} \quad$ el. consumption pumps

$P_{\text {el,heater }} \quad$ el. consumption electrical heater

$P_{\text {el,PV }} \quad$ electricity from $P V$

$P_{\text {el, hh }} \quad$ household electricity consumption

$P_{\text {el,PV,exc }}$ excess electricity from $P V$

$\dot{Q}_{S H} \quad$ useful thermal capacity space heating

$\dot{Q}_{D H W} \quad$ useful thermal capacity $\mathrm{DHW}$

$S P F_{s y s, P V}$ system seasonal performance factor (only considering electricity from the grid)

$W_{\text {el,sys }} \quad$ total el. consumption of the heating system

$W_{\text {el,sys,grid }}$ electricity consumption from grid

$W_{\text {el,feedin }}$ electricity fed into the grid from $\mathrm{PV}$

\section{Results and Discussion}

The simulations were carried out in TRNSYS with a time step of one minute with different variants concerning the size of the PV system and the storage tank volume. The results are shown in Fig. 4 for the radiator heating system for the three control strategies PARALLEL, WIN and WIN\&PV. 

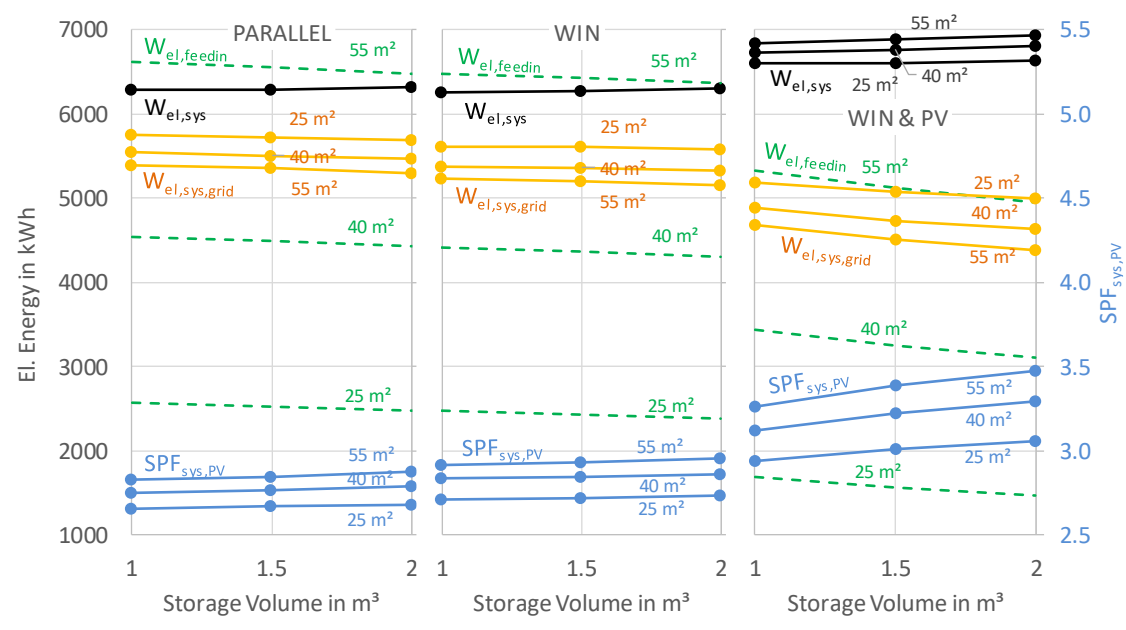

Fig. 4. Annual simulation results for control strategies PARALLEL, WIN and WIN\&PV (from left to right) for the radiator heating system
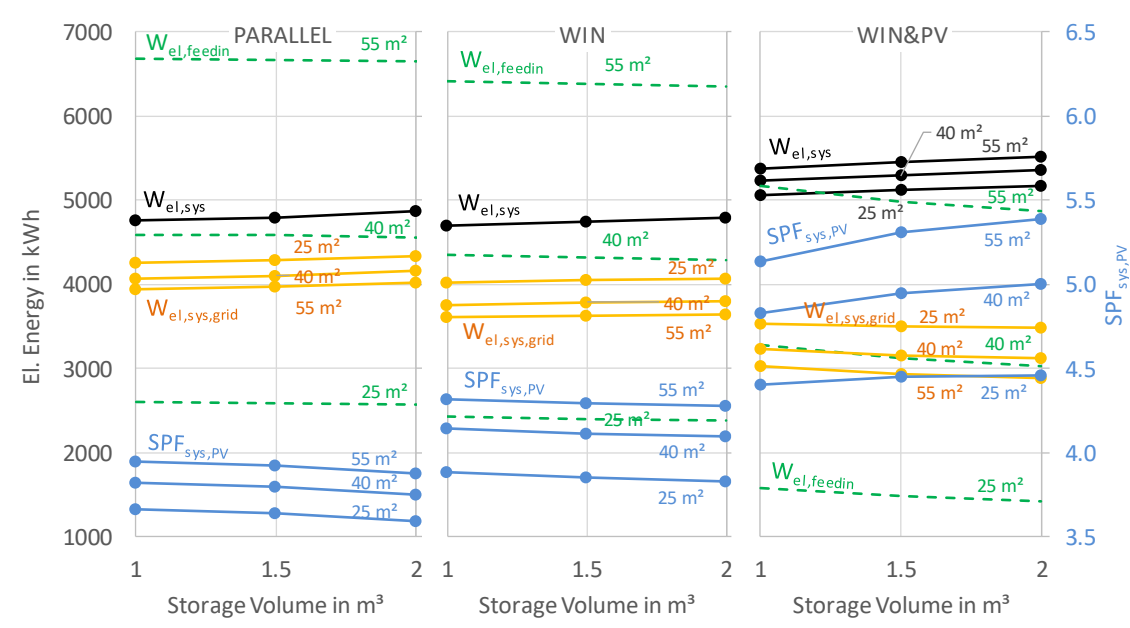

Fig. 6. Annual simulation results for control strategies PARALLEL, WIN and WIN\&PV (from left to right) for the floor heating system

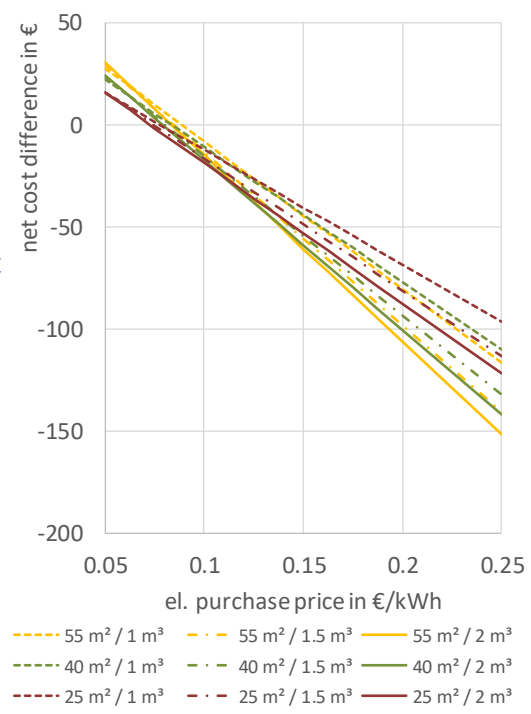

Fig. 5. Net electricity cost difference between strategies PARALLEL and WIN\&PV for radiator heating system

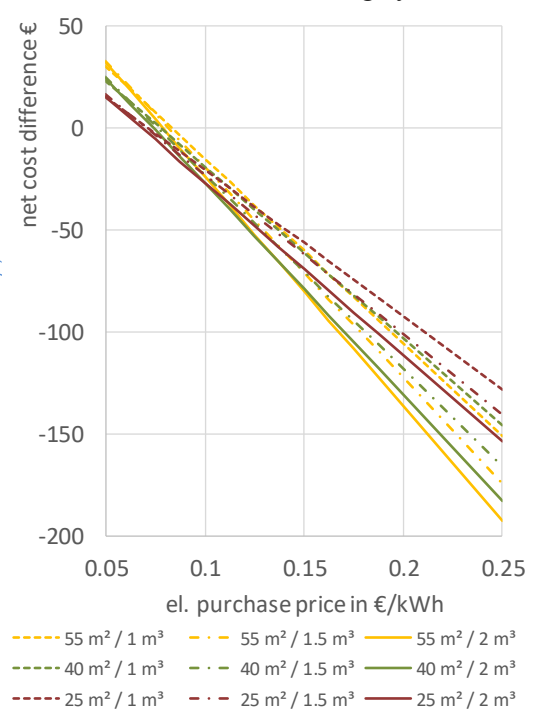

Fig. 7. Net electricity cost difference between strategies PARALLEL and WIN\&PV for the floor heating system
As expected, the electricity consumption from the grid $W_{\text {el,sys,grid }}$ decreases with increasing PV size and with increasing storage volume. Without overcharging of the store (PARALLEL and WIN) the total electricity consumption $W_{e l, s y s}$ is the same for all considered PV sizes and increases slightly due to increased storage losses with larger storage volumes.

The strategy WIN reduces $W_{\text {el,sys,grid }}$ and increases $S P F_{s y s, P V}$ by about 2-3\% in all variants with radiator heating system, as more PV electricity can be used by the heat pump, when DHW charging is only done between 12:00 and 14:00. For comparison Fig. 6 shows the results for the same system with floor heating. As expected the electricity consumption is generally significantly lower and $S P F_{s y s, P V}$ is higher compared to the radiator heating system due to the lower operating temperature. Also the reduction from PARALLEL to WIN is with 5-6 \% (25 $\mathrm{m}^{2}$ $\mathrm{PV})$ to $8-9 \%\left(55 \mathrm{~m}^{2} \mathrm{PV}\right)$ higher than with the radiator system. This is due to the higher supply temperatures of the radiator system, which cause a much lower amount of heat provided by the heat pump in DHW charging mode (50-60\% lower compared to floor heating system), as the tank is heated to relatively high temperatures already in space heating mode. Thus also the saving potential with WIN is lower.

The results for WIN\&PV show a reduction of $W_{\text {el,sys,grid }}$ ranging from $13 \%\left(1 \mathrm{~m}^{3}\right)$ to $17 \%\left(2 \mathrm{~m}^{3}\right)$ for $55 \mathrm{~m}^{2} \mathrm{PV}$ and $10 \%\left(1 \mathrm{~m}^{3}\right)$ to $12 \%\left(2 \mathrm{~m}^{3}\right)$ for $25 \mathrm{~m}^{2} \mathrm{PV}$ compared to the strategy PARALLEL for the radiator system. With floor heating the reduction is even more pronounced, with $23 \%\left(1 \mathrm{~m}^{3}\right)$ to $28 \%\left(2 \mathrm{~m}^{3}\right)$ for $55 \mathrm{~m}^{2}$ $\mathrm{PV}$ and 17 to $20 \%$ for $25 \mathrm{~m}^{2}$. The potential for increasing self-consumption by overcharging the storage tank is significantly lower with the radiator compared to the floor heating system, as higher return temperatures mean, that less storage capacity is available in the buffer storage tank and the COP of the heat pump is lower. 


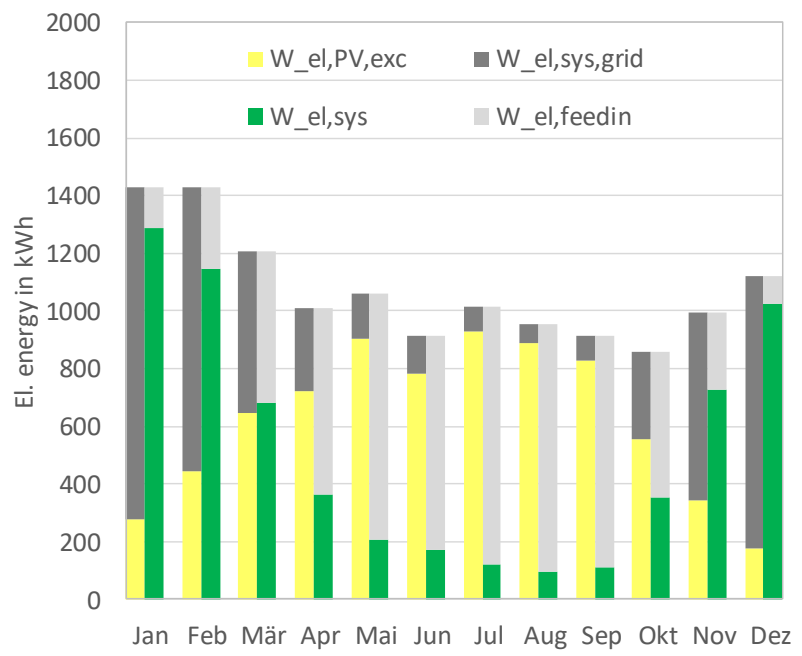

Fig. 8. Monthly electrical energy balance for $55 \mathrm{~m}^{2} \mathrm{PV}$ and $1 \mathrm{~m}^{3}$ storage, control strategy PARALLEL, radiator system

A comparison to a system without PV can be done by comparing $W_{e l, s y s, \text { grid }}$ for WIN\&PV to $W_{e l, s y s}$ for PARALLEL (for which $W_{e l, s y s, \text { grid }}=W_{e l, s y s}$ in a system without PV). The electricity consumption from the grid is reduced by $26 \%\left(1 \mathrm{~m}^{3}\right)$ to $31 \%\left(2 \mathrm{~m}^{3}\right)$ for $55 \mathrm{~m}^{2} \mathrm{PV}$, and $17 \%\left(1 \mathrm{~m}^{3}\right)$ to $21 \%\left(2 \mathrm{~m}^{3}\right)$ for $25 \mathrm{~m}^{2} \mathrm{PV}$ for the radiator system. For floor heating the reduction is $36 \%\left(1 \mathrm{~m}^{3}\right)$ to $41 \%\left(2 \mathrm{~m}^{3}\right)$ for $55 \mathrm{~m}^{2} \mathrm{PV}$, and $26 \%\left(1 \mathrm{~m}^{3}\right)$ to $28 \%\left(2 \mathrm{~m}^{3}\right)$ for $25 \mathrm{~m}^{2} \mathrm{PV}$.

The total electricity consumption $W_{e l, s y s}$ increases for WIN\&PV compared to the strategy PARALLEL due to the heat pump operating at higher condensation temperatures when overheating the storage and due to increased heat losses from the storage tank and the pipes in the system.

While on the one hand the electricity consumption from the grid decreases, as more PV electricity is used by the heat pump, there is on the other hand a reduction of the amount of electricity fed into the grid $W_{\text {el,feedin. }}$. The reduction of feed-in electricity is generally significantly higher than the savings in grid consumption, due to the higher overall consumption $W_{\text {el,sys }}$. For example, for the system with $55 \mathrm{~m}^{2} \mathrm{PV}$ and $1 \mathrm{~m}^{3}$ storage $W_{e l, s y s, P V}$ is reduced by $722 \mathrm{kWh}$, but $W_{\text {el,feedin }}$ decreases by $1280 \mathrm{kWh}$.

Fig. 8 and Fig. 9 shows monthly balances of electrical energy for the strategies PARALLEL and WIN\&PV for the system with $55 \mathrm{~m}^{2} \mathrm{PV}$ and $1 \mathrm{~m}^{3}$ storage. Comparing the figures, it can be seen how the electricity consumption and the feed-in decrease in the different months of the year. Unfortunately, the electricity demand is much higher than the available PV yield during the winter months and vice versa during the summer, which is a common problem of every solar heating application. For a building with a relatively high heating demand and an air source heat pump this is of course even more pronounced.

As on the one hand electricity consumption costs are saved, but on the other hand electricity sellings are decreased, the question arises, if the strategy WIN\&PV

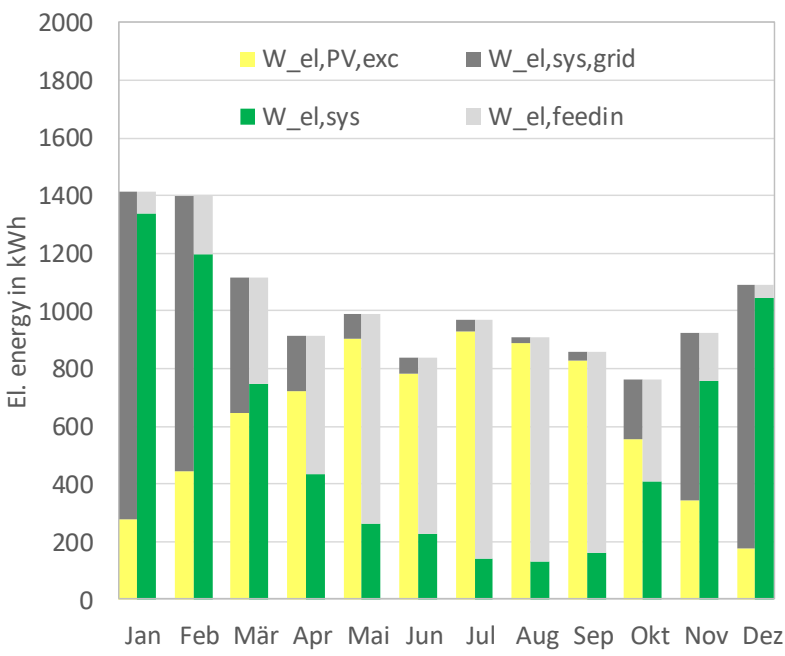

Fig. 9. Monthly electrical energy balance for $55 \mathrm{~m}^{2} \mathrm{PV}$ and $1 \mathrm{~m}^{3}$ storage, control strategy WIN\&PV, radiator system

makes sense from an economical point of view (considering only operating costs). This is obviously dependent on the available feed-in tariff $c_{\text {feedin }}$ and the electricity purchase price $c_{\text {purchase }}$. The net cost difference between the strategies PARALLEL and WIN\&PV, as it is plotted in Fig. 5 and Fig. 7 as a function of the el. purchase price was calculated using equation (6).

$$
\begin{aligned}
& \Delta \operatorname{cost}_{n e t} \\
& =\left(\Delta W_{\text {el,sys,grid,WIN\&PV }}\right. \\
& \left.-\Delta W_{\text {el,sys,grid,PARALLEL }}\right) c_{\text {purchase }} \\
& -\left(\Delta W_{\text {el,feedin,WIN\&PV }}\right) c_{\text {feedin }}
\end{aligned}
$$

For the presented results a feed-in tariff of $0.05 € / \mathrm{kWh}$ was assumed, which is currently a typical value in Austria. Depending on the system cost savings (negative net cost difference) are achieved for purchase prices higher than approximately 0.07 to $0.09 € / \mathrm{kWh}$. In general, there is a saving if the purchase price is 1.4 to 1.8 times higher than the feed-in tariff, independent on the absolute values. For floor heating the savings are generally higher than for the radiator system due to the higher reduction of purchased electricity.

For example with a purchase price of $0.15 € / \mathrm{kWh}$ the cost savings are between 40 and $60 € / \mathrm{a}$ for the radiator system and 56 to $80 € / \mathrm{a}$ for floor heating.

\section{Summary and Outlook}

The results of the performed analysis show that hybrid systems combining an air-source heat pump with PV are a possibility to significantly reduce the electricity consumption and the operative costs of heating systems in renovated buildings with relatively high supply temperatures.

With the assumed boundary conditions targeted operation of the heat pump, as demonstrated here with the control strategy WIN\&PV, shows to be profitable 
compared to a simple PARALLEL operation, if the electricity purchase price is at least 1.4 to 1.8 times higher than the available feed-in tariff.

With the demonstrated system and building with a heating demand of about $12200 \mathrm{kWh}$ and a DHW demand of roughly $3000 \mathrm{kWh}$ the electricity consumption from the grid can be reduced to overall (now also considering household electricity) $6781 \mathrm{kWh}$ with for example $55 \mathrm{~m}^{2}(9.3 \mathrm{kWp})$ of $\mathrm{PV}$ and a water storage volume of $1 \mathrm{~m}^{3}$, compared to $9342 \mathrm{kWh}$ without PV. Additionally, $5333 \mathrm{kWh}$ of PV electricity can be fed into the grid, resulting in a reduction in electricity costs from $1400 € /$ a without PV to $750 € / \mathrm{a}$, assuming an electricity purchase price of $0.15 € / \mathrm{kWh}$ and a feed-in tariff of 0.05 $€ / \mathrm{kWh}$.

For the same building with a floor heating system the results are - not surprisingly - better concerning the electricity consumption. Also the saving potential by driving the compressor of the heat pump with PV is higher $(23 \%$ with $1 \mathrm{~m}^{3}$ storage and $55 \mathrm{~m}^{2} \mathrm{PV}$ ) compared to the radiator system $(13 \%)$. This is due to the higher temperature difference available in the storage tank and the therefore higher capacity for storing surplus heat generated by driving the heat pump with PV. Additionally, the COP is higher with lower supply temperatures, thus more $\mathrm{kWh}$ of heat can be generated out of $1 \mathrm{kWh}$ PV electricity.

An interesting aspect about the results is that the radiator system with $\mathrm{PV}\left(55 \mathrm{~m}^{2}\right)$ consumes about the same amount of electricity from the grid as the system with floor heating and without PV. Due to the additional feedin of PV electricity into the grid about $36 \%$ of electricity costs can be saved with the tariffs mentioned above. Of course a low temperature heating system should always be preferred when using a heat pump and could achieve even much better overall results when combined with PV. But reality shows that heat emission systems are often not replaced during renovations and for such systems a combination with $\mathrm{PV}$ can be one possibility to significantly save energy and $\mathrm{CO}_{2}$ emissions.

Finally, it has to be mentioned that of course also the climate has an influence on the performance of such systems, especially the ambient temperature and available solar radiation during winter, which is relatively low in the here used climate data set. First simulations with climate data of the city Graz (average climate of the years 2000 to 2010) show better results. Also a ground source heat pump could be an attractive (yet not so easy to install) alternative for such systems, as significantly higher COPs can be achieved during winter, which means that more $\mathrm{kWh}_{\text {th }}$ can be generated out of one $\mathrm{kWh}_{\mathrm{el}}$ from PV during the months with the majority of the heat demand.

\section{Acknowledgements}

This project is funded by the Austrian Climate and Energy Fund and is carried out as part of the Energy Research Programme 2016.

\section{References}

[1] M. Amtmann, 'Scientific Report D6.9: Reference buildings - The Austrian building typology, A classification of the Austrian residential building stock. IEE - Intelligent Energy Europe.'

Österreichische Energieagentur - Austrian Energy Agency, 2010.

[2] M. Battaglia, R. Haberl, E. Bamberger, and M. Haller, 'Increased self-consumption and grid flexibility of PV and heat pump systems with thermal and electrical storage', Energy Procedia, vol. 135, pp. 358-366, Oct. 2017.

[3] A. Thür, T. Calabrese, and W. Streicher, 'Smart grid and PV driven ground heat pump as thermal battery in small buildings for optimized electricity consumption', Solar Energy, vol. 174, pp. 273-285, Nov. 2018.

[4] A. Toradmal, T. Kemmler, and B. Thomas, 'Boosting the share of onsite PV-electricity utilization by optimized scheduling of a heat pump using buildings thermal inertia', Applied Thermal Engineering, vol. 137, pp. 248-258, Jun. 2018.

[5] C. Bales, A. Heinz, and M. Haller, 'Deliverable 7.1 - Definition of Boundary Conditions, FP7 project MacSheep (grant agreement 282825)', 2012.

[6] 'TABULA WebTool'. [Online]. Available: http://webtool.building-typology.eu/?c=all\#bm. [Accessed: 31-Jan-2018]

[7] R. Dott, M. Y. Haller, J. Ruschenburg, F. Ochs, and J. Bony, 'The reference framework for system simulations of the IEA SHC Task 44/HPP Annex 38 Part B: buildings and space heat load', International Energy Agency, 2013.

[8] 'LoadProfileGenerator'. [Online]. Available: http://www.loadprofilegenerator.de/. [Accessed: 07Mar-2018].

[9] N. D. Pflugradt, 'Modellierung von Wasser- und Energieverbräuchen in Haushalten', Dissertation, Technische Universität Chemnitz, 2016.

[10] U. Jordan and K. Vajen, 'DHWcalc - Tool for the Generation of Domestic Hot Water (DHW) Profiles on a Statistical Basis'. Universität Kassel, Institut für Thermische Energietechnik, 2012.

[11] M. Biberacher, 'Räumliche Modelle als Entscheidungsgrundlage für die Inwertsetzung regional verfügbarer Energiepotenziale zur CO2neutralen Deckung des lokalen Wärmebedarfs', 2010.

[12] E.-R. Schramek and H. Recknagel, Taschenbuch für Heizung + Klimatechnik 07/08. Oldenbourg Industrieverlag, 2007.

[13] R. Dott et al., 'Models of sub-components and validation for the IEA SHC Task 44/HPP Annex 38 Part C: heat pump models', International Energy Agency, A technical report of subtask C Deliverable $C$, vol. 2, 2013.

[14] 'Amtblatt L239 der Europäischen Union, DELEGIERTE VERORDNUNG (EU) Nr. 812/2013'. 06-Sep-2013. 